\author{
МИХАИЛ ПРИШВИН О СЧАСТЛИВЫХ ОСЛАХ \\ И ЛЕСТНИЦЕ СЧАСТЬЯ ДЛЯ ВСЕХ И КАЖДОГО*
}

Наталья Дворцова

Тюменский государственный университет,

Тюмень, Россия

\title{
MIKHAIL PRISHVIN ON HAPPY DONKEYS AND THE LADDER OF HAPPINESS FOR EACH AND FOR ALL
}

\author{
Natalia Dvortsova \\ Tyumen State University, \\ Tyumen, Russia
}

This article is the first attempt to determine the structure and dynamics of the 'text of happiness' in M. M. Prishvin's works, including his Diaries (1905-1954) in their unabridged and uncensored version, the short stories The Pharmacy of Happiness (1915) and Hunt for Happiness (1926), the essay Old Vita (1918), the poem Phacelia (1940), the fairytale Mast-Tree Grove (1954), and the diary book You and I. The author searches for new approaches to Prishvin's prose, including fiction published in the Soviet and post-Soviet periods, eighteen volumes of his Diaries published from 1991 to 2017, and The Colour and the Cross collection (published in 2017). The research methodology is based on a reconstruction and motif analysis of Prishvin's text of happiness in terms of its structure and dynamics from 1905 to 1954. The text of happiness in Prishvin's prose relates to the topics of personal fate, a life journey existing between individual and common being (natural, social, and transcendental), and the freedom to create one's own destiny. According to Prishvin, happiness is universal, unconditional, ephemeral, and has innumerable forms. Prishvin's path to his own happiness is a story of critical reflection and distancing from the Marxist (1900-1920s), Nietzschean (the turn of the 1940s), and Soviet atheistic understanding of happiness (1930-1950s). A central strand of this

* Citation: Dvortsova, N. (2019). Mikhail Prishvin on Happy Donkeys and the Ladder of Happiness for Each and for All. In Quaestio Rossica. Vol. 7, № 3. P. 721-735 DOI 10.15826/qr.2019.3.403.

Цитирование: Dvortsova N. Mikhail Prishvin on Happy Donkeys and the Ladder of Happiness for Each and for All // Quaestio Rossica. Vol. 7. 2019. № 3. P. 721-735. DOI 10.15826/ qr.2019.3.403 / Дворизова Н. Михаил Пришвин о счастливых ослах и лестнице счастья для всех и каждого // Quaestio Rossica. T. 7. 2019. № 3. C. 721-735. DOI 10.15826/qr.2019.3.403. 
story is defending one's right to be true to oneself and "to stand on one's own rock". Prishvin's text of happiness recreates a unique life experience in the first half of the twentieth century as an individual transitions from unhappiness to happiness: part of this experience is a feeling of shame about one's own happiness and the happiness of self-destruction. The text of happiness in Prishvin's literary oeuvre is structured with a system of leitmotifs, each of which is realised through a system of individual motifs. The author considers the evolution of the motif of the hunt for happiness, reconstructing the evolution of the motif of happiness for all and everyone: from Prishvin's defence of the personal right to happiness (1900-1920s) to his recognition of equal rights for one and all when at the turn of the 1940s, when, after experiencing the trauma of Soviet collectivism, he began looking for new forms of human unity. His fairytale Mast-Tree Grove is interpreted not as the end of Prishvin's understanding of happiness but as one step on the ladder.

Keywords: M. M. Prishvin; Prishvin studies; motif of happiness; text of happiness; Marxism; Nietzscheanism.

В статье впервые выявляются структура и динамика текста счастья в творчестве М. М. Пришвина, включающего в себя «Дневники» 1905-1954 гг. в их полной 18-томной нецензурированной версии, рассказы «Аптека счастья» (1915), «Охота за счастьем» (1926), очерк «Старушка Vita» (1918), поэму «Фацелия» (1940), повесть-сказку «Корабельная чаща» (1954), дневниковую книгу «Мы с тобой» (1996). Актуальность работы определяется поиском новых подходов к изучению прозы Пришвина в ее нынешней целостности, представленной, помимо художественных произведений, изданных в советские и постсоветские времена, 18 томами «Дневников», издававшихся с 1991 по 2017 г., и книгой «Цвет и крест» (2017). В основе методологии исследования - реконструкция и мотивный анализ пришвинского текста счастья в его структуре и динамике - от 1905 к 1954 г. Текст счастья в творчестве Пришвина связан прежде всего с темой личной судьбы, жизненного пути человека, существующего между индивидуальным и общим (природным, социальным, трансцендентным) бытием, а также с проблемой свободы человека творить собственную жизнь. Счастье, по Пришвину, универсально, безусловно, бесчисленнолико и эфемерно. Путь Пришвина к собственному счастью - это история критического осмысления и дистанцирования от марксистского (1900-1920-е гг.), ницшеанского (рубеж 1930-1940-х гг.) и советского атеистического (1930-1950-е гг.) понимания счастья, трудное отстаивание права быть самим собой, стоять «на своем камне». Текст счастья Пришвина воссоздает уникальный опыт жизни человека первой половины XX в., переходящего от несчастья к счастью, включающему в себя чувство стыда за собственное счастье и счастье самоуничтожения. Структурируется текст счастья в творчестве Пришвина системой лейтмотивов, каждый из которых реализуется в системе частных мотивов. Раскрыта эволюция мотива охоты за счастьем. Воссоздана эволюция мотива счастья всех и каждого: от защиты писателем права на счастье каждого (1900-1920-е гг.) до признания равенства прав каждого и всех, когда При- 
швин на рубеже 1930-1940-х гг. от переживания травмы советского коллективизма переходит к поиску новых форм человеческого единства в русле народной и христианской традиции. Повесть-сказка «Корабельная чаща» интерпретируется не как итог пути Пришвина в осмыслении счастья, а как одна из его ступеней на лестнице счастья.

Ключевые слова: М. М. Пришвин; пришвиноведение; мотив счастья; текст счастья; марксизм; ницшеанство.

С началом публикации «Дневников» М. М. Пришвина на рубеже 19801990-х гг. в сознании читающей публики и историков литературы стало складываться представление о нем как писателе неоткрытом и неизвестном [Варламов; Подоксенов]. Оно явилось на смену различным версиям единой в литературоведении 1950-1980-х гг. концепции жизни и творчества Пришвина как «сложного и трудного пути» художника, пришедшего к социалистическому реализму «с грузом заблуждений» Серебряного века и отстоявшего свое право существовать в советской литературе «со своим путиком» [Хмельницкая; Хайлов; Ершов; Курбатов].

С завершением в 2017 г. публикации «Дневников» Пришвина в их полной 18-томной нецензурированной версии [Рязанова, с. 3] начинается новый этап осмысления творческого пути писателя. Впервые у литературоведов и читающей публики появилась возможность понять все написанное Пришвиным в тайных «Дневниках» (1905-1954), доступных сегодня не только на бумаге, но и в «цифре» [Электронная библиотека М. М. Пришвина], и в художественных произведениях, опубликованных в советский и постсоветский периоды. И пока в Интернете продолжаются дискуссии на темы «Пришвин и Гитлер», «Пришвин и антисемитизм» и т. п., открывающие новый образ писателя, в литературоведении идут поиски новых подходов к его творчеству.

Очевидно, закономерно поэтому появление новой тенденции, пришедший на смену системным концепциям и характеризующейся вниманием к локальному, в частности, к конкретным элементам поэтики писателя, как это делает, например, Е. А. Худенко [Худенко, c. 107-118]. В русле этой тенденции - нового открытия поэтики прозы Пришвина - создана данная работа о тексте счастья, структурированном в творчестве писателя системой мотивов счастья.

В книге «Незабудки» (1969), созданной В. Д. Пришвиной на основе «Дневников» М. М. Пришвина 1905-1954 гг. и состоящей, по завещанию писателя, из основных (36 - по числу глав) тем и мотивов его творчества, мотив счастья/несчастья в их ряду отсутствует. Вместе с тем его «Ранний дневник» (1905-1913) начинается с мотива несчастья [Пришвин, 2007, с. 5]. В последнем произведении Пришвина, завершенном за месяц до его смерти, повести-сказке «Корабельная чаща», а также в «Дневниках» 1952-1954 гг. тема счастья - одна из основных.

Существуя на периферии творческого сознания Пришвина, мотив счастья/несчастья, таким образом, является сквозным, сопровожда- 
ющим его на протяжении всей жизни, что и определяет задачи этого исследования: 1) реконструировать текст счастья в творчестве Пришвина, обозначив входящие в него произведения, выявив его мотивную структуру и динамику; 2) понять логику развития мотива счастья в контексте творческого пути Пришвина, писателя Серебряного века, становящегося признанным советским писателем. Новизна работы обусловлена не только предметом исследования (текст счастья в творчестве Пришвина, структурированный мотивами счастья), но и его материалом, представленным «Дневниками» Пришвина в их целостности, а также впервые опубликованной книгой прозы писателя 1906-1924 гг. «Цвет и крест» (2017), включающей в себя, в частности, рассказ «Аптека счастья» (1915) и очерк «Старушка Vita» (1918). Работа создана в русле современных исследований счастья [Топография счастья; Добренко; Лоргус; Чинакова] и представляет собой первое системное исследование текста счастья в творчестве («Дневниках» и художественных произведениях) Пришвина, осуществленное на основе мотивного анализа локального текста [Гаспаров].

\section{Счастье и несчастье - две меры судьбы}

В «Раннем дневнике» (1905-1913) и рассказе «Аптека счастья» (1915), структурирующих текст счастья Пришвина досоветского периода, мотив счастья существует в оппозиции «счастье - несчастье» и напрямую связан с темой судьбы, жизненного пути человека и проблемой соотношения между индивидуальным и коллективным бытием, а следовательно, счастьем личным и всеобщим, достигаемым революционным путем.

В «Раннем дневнике» мотив счастья является важнейшим в разделе «Любовь», носит биографический характер и связан с историей отношений Пришвина с В. П. Измалковой и Е. П. Смогалевой. «Счастье и несчастье - это две богини - как их назвать! Такие богини, которых держат в уме, чтобы объяснить непонятное», - пишет автор [Пришвин, 2007, с. 139]. Свои отношения с женой он называет счастьем и несчастьем одновременно [Там же, с. 141, 104]. В 1912 г. в «Раннем дневнике» возникает завершенная афористическая формула: «...счастье и несчастье - это только две меры судьбы: счастье - в ширину, несчастье - в глубину» [Там же, с. 136]. Формулу эту Пришвин повторит позднее, в 1926 г., в рассказе «Охота за счастьем».

«Ранний дневник» отражает реальный опыт пришвинского переживания счастья как особого чувства природной жизни. Автор называет его «счастливым режущим чувством чего-то святого» [Там же, с. 6]. Мотив счастья в его особом значении - как цели революционного движения и вместе с тем замены и подмены естественного семейного счастья человека - связан здесь с увлечением Пришвина марксизмом, приведшим к его аресту в 1897 г. и году одиночного тюремного заключения. В разделе «Начало века» он пишет об этом, осмысляя весь свой путь: 
Два светила восходят в сознании русского мальчика конца прошлого века: Маркс, а потом Ницше. Маркс стоит во главе движения, цель которого есть счастье среднего человека... Ницше - представитель иной цели - сверхчеловека, личности... быт в России разлагается, семейная жизнь теряет всякий образ. <..> На пустом месте становится идеал общего счастья и мыслимая близость с несчастными всех стран - пролетариями [Там же, с. 300, 302].

Своего рода итогом размышлений Пришвина о счастье в 19001910-е гг. является рассказ «Аптека счастья» (1915), который можно назвать притчей о немецком счастье, русском несчастье и невозможности всеобщего счастья. В центре рассказа - история Вильгельма Федоровича, которому «трудно было... где-то в русской глухой провинции, но он все-таки никогда не падал духом, не расставался с мечтой о службе в большой-большой аптеке, в большом-большом городе и даже о собственной аптеке». Вильгельм Федорович «скопил порядочную сумму денег, взял отпуск на месяц», обошел все аптеки в Петербурге и, наконец, в последней «добился места провизора». Во время войны 1914 г. он, защищая свое счастье, сменил имя, стал русским человеком Василь Василичем [Пришвин, 20176, с. 295].

История фрау Вейс, которая на Малой Охте с ее «невылазной грязью, капустниками, лачугами пропащих столичных людей» создала рядом со своим домом сад с сиренью, соловьями, граммофоном и играющими детьми, вроде бы подтверждает мысль о том, что человек сам, своими силами и в любых условиях может устроить собственное счастье. Однако история мужа фрау Вейс, больного фабриканта, у которого «не было вкуса к немецкому счастью, не было охоты его достигать», и он в этом смысле «был очень похож на русского» [Там же, с. 296], опровергает эту мысль и переводит сюжет о достижении счастья на метафизический уровень. И немецкое счастье, и русское несчастье оказываются явлением таинственным, непостижимым, не зависящим, как и судьба, от усилий человека. Более того, не существует общего счастья, и каждый по-своему несчастен. Важно подчеркнуть, что накануне событий 1917 г. вопрос о счастье для Пришвина - это не вопрос о революции и ее целях, а о личности и ее судьбе, предопределенности судьбы и свободе человека творить ее самому.

\section{«Старушка Vita» и «Охота за счастьем»}

Текст счастья в творчестве Пришвина 1920-х гг., помимо «Дневников» этого периода, представлен автобиографическим рассказом «Охота за счастьем» (1926). Писатель вновь дистанцируется здесь от идеи всеобщего счастья, достигнутого путем революционного насилия, и, опираясь на авторитет Л. Н. Толстого («Человек обязан быть счастлив»), пишет о свободе человека творить счастье собственной 
жизни вопреки власти судьбы, олицетворением которой становится для него революция.

Своего рода предисловием к истории мотива счастья в творчестве Пришвина в советский период является очерк «Старушка Vita» (1918). Поводом для его возникновения послужила, как пишет Пришвин, публикация в одной советской газете, где в отделе «Местная жизнь» «было напечатано, что вместе с ворами и разбойниками за контрреволюционную деятельность расстреляны родственники наши». «В провинции, - пишет об этой ситуации Пришвин, - все родня» [Пришвин, 20176, с. 220].

История «нескольких без суда казненных где-то в провинции человечков» заставляет его сделать вывод о катастрофических последствиях «большевистского бунта»:

Обыватель отказывается от счастья всего человечества, если ради этого делается небольшой пропуск: жизнь человека знакомого. Наоборот, обыватель острова Советской республики готов ради человечества пропустить и всю жизнь, старушку Vita... при нынешних наших исследованиях мы пропускаем старушку Жизнь [Там же, с. 220].

В «Дневниках» 1927 г. Пришвин пишет:

Нет, не верю я больше никакому общему счастью, никакому общему слову, пока не разгляжу за ним жизнь отдельного существа [Пришвин, 2003, c. 498].

Тема старушки Vita в 1920-е гг. превращается в ключевую для творчества Пришвина идею «оправдания бытия», жизни как «основы всего», важнейшим атрибутом (свойством) которой является счастье. Главным итогом революции станет для него мысль о том, что «пережить несчастье и выйти из него с радостью ко всему живущему... есть подвиг... за который человек награждается истинной свободой» [Там же, с. 216]. В «Охоте за счастьем» Пришвин назовет несчастье «этапом в творчестве счастья» [Пришвин, 1982-1986, т. 3, с. 14].

Из размышлений писателя о возрождении жизни после революции как несчастья, которое необходимо пережить, чтобы вновь ощутить счастье жизни, с нашей точки зрения, и рождается автобиографический рассказ «Охота за счастьем». С рассказом «Аптека счастья» его объединяет тема двойной загадочной природы счастья, которое, с одной стороны, необъяснимым образом дается даром, а, с другой, достигается трудом, усилиями и даже ухищрениями (вплоть до смены героем имени). Амбивалентный в своем значении образ охоты за счастьем также, с нашей точки зрения, восходит к образу охоты/ неохоты достижения счастья в «Аптеке счастья».

В «Дневниках» 1920-х гг. слова «охота», «охотник» Пришвин использует в трех основных словосочетаниях: «охотник жизни», «охо- 
та за червонцами», «охота за счастьем». «Охотой за червонцами» он называет свое ремесло журналиста - создание произведений, обращенных к читателю-современнику, публикация которых дает возможность обеспечивать семью. Охотники жизни, с его точки зрения, это художники и торговцы, которых объединяет «страсть к веществу жизни и расположение на счастье, на судьбу, на случай... зоркость глаза и мертвая хватка, когда увидел свое» [Пришвин, 1999, с. 103]. О природе страсти охотника (поэта в душе) и художника Пришвин пишет также:

Редко охотник отдает себе отчет в том, что очаг его страсти не в румянце зари, а в пламени пороха, выбрасывающего свинец в живую тварь. Охотник предвкушает наслаждение впустить свинец в живое тело.

И дело здесь, утверждает он, «не в поэзии, а в овладении предметом страсти: птица должна быть убита» [Там же, с. 312].

Об издании своей первой книги «В краю непуганых птиц» и о своем вхождении в литературу в «Охоте за счастьем» Пришвин пишет:

Я схватил свое счастье, как птицу на лету, одним метким выстрелом. Но мало того, что я схватил, мне кажется, я тут же и посолил свое счастье, чтобы оно не испортилось [Пришвин, 1982-1986, т. 3, с. 17].

Образ счастья как соленой мертвой птицы - не только свидетельство пришвинского понимания современного ему «цивилизованного» человека, в душе которого «продолжает обитать инстинкт дикаря» [Там же, с. 12], но и свидетельство двойственности, амбивалентности самого счастья, достижение которого становится его утратой. Поэтому, очевидно, Пришвин воссоздает множество эпизодов своей жизни, каждый раз заново повторяя слова о своем счастье или даже величайшем счастье, которое он испытал в том или ином случае. И рассказ о жизни как охоте за счастьем оказывается рассказом о счастье как эфемерном, но безусловном свойстве самой жизни.

Дневник 1926 г. завершается у Пришвина словами: «Это был год для меня исключительно счастливый, проведенный у родников Берендеева царства» [Пришвин, 2003, с. 175]. Он перечисляет главное, что произошло в его жизни в этом году. Публикация рассказа «Охота за счастьем» в ряду этих событий отсутствует. Вместе с тем 5 декабря Пришвин пишет:

Рассказ «Охота за счастьем», несомненно, имеет глубочайший успех в обществе, вероятно, тема о «счастье» - теперь общественная тема. Оно и понятно: очень люди намучились [Там же, с. 135, 167].

Успешным «Охоту за счастьем», очевидно, делало то, что это приключенческий рассказ о человеке в поисках счастья, в которых ему нередко помогает охотничье ружье. Это, кроме того, история 
о человеке, которому счастье не только дается как случай, чудо, но который достигает его в борьбе с многочисленными препятствиями. Как счастливый случай Пришвин оценивает свое первое и второе вхождение в литературу. Если первое он связывал с тем, что его «писания имели успех прежде всего в высших литературных кругах» [Пришвин, 1982-1986, т. 3, с. 18], то второе - с тем, что рассказ совпал с настроениями людей, намучившихся, как он пишет, в годы революции и вернувшихся после возрождения жизни к естественному ощущению счастья жить. Принципиален еще и тот факт, что созвучным настроениям людей оказался рассказ, в котором Пришвин отстоял свое право быть самим собой и писать об охоте, природе и детстве.

\section{«Фацелия»: от травмы коллективизма к поиску нового единства}

Текст счастья в творчестве Пришвина на рубеже 1930-1940-х гг., времени, переломном в его судьбе, помимо «Дневников», включает в себя поэму «Фацелия» (1940) и дневниковую книгу «Мы с тобой», созданную совместно с В. Д. Пришвиной и впервые опубликованную в 1996 г.

Семантика мотива счастья в 1930-1950-е гг., с нашей точки зрения, определяется духовным переворотом писателя, совпавшим с его встречей с В. Д. Лиорко (В. Д. Пришвиной) [Пришвин, 2012, c. 317]. Важнейшим свидетельством этого переворота стал тот факт, что во время переписи населения в январе 1937 г. он, «чтобы постоять за себя», признал себя человеком православным. Он пишет в «Дневниках»:

Православие - это моя связь со всей моей родиной, и в нем таится для моего нравственного сознания готовность идти к желанному счастью через страдание и, если понадобится, через смерть [Пришвин, 2010, с. 441].

Духовный переворот становится для Пришвина переоценкой всех сторон собственной мысли и жизни. В контексте темы счастья принципиальное значение имеет переосмысление Пришвиным отношений всех и каждого, возращение всем их созидательной роли, движение его мысли от реальной ситуации «насилия всех над каждым» к понятию «мы» («мы с тобой») в его глубочайшем религиозном смысле, когда становится ясно, что «тайна Вселенной - в понятии “мы”, причем “мы” означает первоначально “мы с тобой”, а вглядеться поглубже - это вся Вселенная» [Пришвин, Пришвина, с. 337].

Можно утверждать, что от переживания травмы советского коллективизма («насилия всех над каждым») Пришвин приходит к поиску новых форм человеческого единства, которое для него существует не столько как теоретическая проблема, сколько как ре- 
альный опыт внутри самой жизни. Актуальным для него становится не столько отказ от идеи общего коммунистического счастья для всех, сколько критическое осмысление способа и формы его собственного противостояния этой идее. Эту форму противостояния в 1940 г. он назовет «формой охотника и ницшеанца», а свою жизнь со времени возвращения из Германии до встречи с В. Д. Пришвиной оценит как «кокетливую игру в уединенного человека, как одну из форм эстетического демонизма. Странническое блуждание по неустроенной стране в костюме охотника с дикаркой и детьми, вызов мещанскому обществу и т. д. - все до точности происходит от ницшеанского сверхчеловека в русском издании», - пишет он [Пришвин, 2012, с. 257]. Оба кумира его юности - Маркс и Ницше окажутся поверженными, а счастье своей прошлой жизни Пришвин оценит как мнимое (ложное) и глупое (ослиное): «Это настоящий переворот, переход от “счастливой” и глупой, застоявшейся жизни к серьезной» [Там же, с. 122].

Новое понимание счастья наиболее полно предстает в поэме «Фацелия», которую, с нашей точки зрения, можно назвать пришвинской энциклопедией счастья: в ней сосредоточены едва ли не все мотивы, связанные с этой темой. В их ряду - мотивы, традиционные для Пришвина: счастья как «острого чувства природы», «счастливых мгновений» при встрече человека и природы («лови мгновенье, как дитя, и будь счастлив»); счастья, которое добывается неустанным трудом и дается даром, так что ключом к нему может стать что угодно, например, «венчик крохотной гвоздики», поэтому надо трудиться над счастьем, но придет оно само. В «Фацелии» наиболее отчетливо, чем ранее, выражена мысль Пришвина о ступеньках (лестнице) счастья и о ложном счастье. Он говорит в «Фацелии» о счастье всех (вне контекста марксистской идеи): «не я один, а и все могли бы быть счастливы... счастье творческое могло бы сделаться религией человечества». Кроме того, «любовь есть счастье».

Образ охотника в «Фацелии», в отличие от «Охоты за счастьем», представлен не как образ победителя, метким выстрелом добывающего свою птицу счастья, а как образ человека, потерпевшего внешнее поражение, но одержавшего внутреннюю победу: мотив «охотник, охотник, отчего ты тогда ее не удержал» перейдет в «Фацелию» из «Женьшеня». На месте «охотника и ницшеанца» из «Охоты за счастьем» в «Фацелии» появится обычный человек, счастье которого «быть, как все хорошие люди» [Пришвин, 1982-1986, т. 5, с. 11, 15, $16,24,42]$. Важно подчеркнуть, что и само счастье предстанет в «Фацелии» не как мертвая соленая птица из «Охоты за счастьем», а как множество чудесных синих птиц, прилетевших из далекой страны и оставивших после себя «свои синие перья» - «яркое поле цветов» «медоносной травы фацелии» [Там же, с. 6, 7]. Сам образ «поля синих цветов», где каждый и все соединились в гармоническое единство 
целого, очевидно, является одним из предшественников образа корабельной чащи из повести-сказки Пришвина.

На рубеже 1930-1940-х гг. Пришвин дистанцируется не только от ницшеанского, но и от советского атеистического понимания счастья, отстаивая свое право быть счастливым на общем человеческом, освященном христианской идеей пути страдания и радости.

\section{Рецепт счастья с первой ступени его лестницы}

В 1950-е гг., последние годы жизни Пришвина, текст счастья в его творчестве представлен повестью-сказкой «Корабельная чаща» и «Дневниками», которые можно рассматривать как своего рода леса к повести.

Один из лейтмотивов «Дневников» - грядущее и свершившееся 80-летие (5 февраля 1953 г.), заставившее автора так или иначе подводить итоги собственной жизни. Он пишет: «По правде сказать, жил я свои 80 лет как счастливый и настоящего горя не знал». В декабре 1953 г., немногим более чем за месяц до смерти, он напишет о своей жизни: «Я лично понимаю себя неудачником, достигающим счастья» [Пришвин, 2017a, с. 316, 493]. «Дневники» Пришвина, таким образом, начинаются в 1905 г. с мотива несчастья и завершаются мотивом счастья. Во многом это обусловлено историей его любви, встречей в 1940 г. и совместной жизнью с В. Д. Пришвиной. В январе 1953 г. в памятный день этой встречи он напишет: «За нами осталось тринадцать лет нашего счастья» [Там же, с. 271].

Главное, с нашей точки зрения, состоит в том, что свою счастливую жизнь за несколько дней до смерти Пришвин оценивает всего лишь как «первую площадку» на лестнице счастья, а свое состояние автора только что вышедшей книги «Весна света» - как состояние счастливого осла. Он пишет: «Похоже, будто вступил по лестнице счастья на первую площадку. Площадок на лестнице много, и, пока доберусь, не принялись бы меня подгонять, как счастливого осла» [Там же, с. 507].

Идея лестницы счастья в «Дневниках» Пришвина становится более понятной в связи с другой его идеей - величайшего разнообразия счастья жизни. Представление писателя о бесконечном разнообразии его форм, как нам кажется, может соперничать в его творчестве только с его пониманием природы как бесчисленноликого небывалого, в наиболее завершенном виде представленном в «Книге бытия» Пришвина «Календарь природы» (1925-1935).

Прежде всего важен тот факт, что счастье у Пришвина - это способ существования не только человека, но и всей живой природы: «жизнь есть счастье». Так, он расскажет о «собачьем счастье» или о том, что земля, «как счастливый человек, в сорочке родится». В жизни человеческой он различает счастье детства, молодости, семейное, старости, а также «последнее и окончательное», кажущееся недостижимым счастье войти «в царство Твое вечное», Царство Божье. Чувствовать 
себя «в руках Божьих» для автора счастье [Там же, с. 75, 103, 112, 140, 372, 204, 419].

Все эти ступени лестницы счастья являются, по Пришвину, «раскрытием существа личности», поэтому «путь счастливых», помимо естественного физического счастья (не болеть, не быть калекой), это переживание «счастья свободы», «счастья творчества», счастья быть собой и вместе с тем быть, как все хорошие люди, особенного счастья писателя и т. д. Счастье, с точки зрения Пришвина, может быть неверным, невыразимым, но оно по-прежнему, как и в «Раннем дневнике», будет «обжигающим чувством» [Там же, с. 13, 17, 151, 153, 231, 234, 359, 391, 134, 103].

Пришвинская философия счастья будет неполной без акцентирования мотива стыда за собственное счастье: стыдно быть счастливым, когда «жертвы безмолвствуют». В ситуации, когда вопрос о счастье сталкивается с «лесом этических вопросов», он пишет, например:

Можно ли быть счастливым, когда все близкие люди умерли и знаешь, что сам дышишь на ладан, а главное, нечто такое познал, перед чем все искусство - только игра, а деятели его - недоросли, шалуны [Там же, с. 77, $146,257]$.

Здесь есть также апокалиптический мотив счастья гибели, самоуничтожения:

...загорается в душе пожар, подобно староверскому самосожжению... И втайне даже хочется, как счастья, чтобы все сгорело и сам со всем сгорел [Там же, с. 339].

Можно утверждать, что «Дневники» Пришвина фиксируют богатейший сокровенный опыт счастливой жизни человека в условиях советской жизни начала 1950-х гг.

«Дневники» 1950-х гг. воссоздают поиск ответов на вопросы, появившиеся у писателя уже в 1890-е гг. Все эти вопросы-ответы так или иначе тяготеют к двум: о счастье всех и каждого и о счастье и правде. $\mathrm{O}$ «рецепте счастья для всех» Пришвин пишет:

Единственное для всех я могу сказать, что каждый должен непременно сам взяться за это и достигнутое самим обратить в пример для других (подчеркнуто М. М. Пришвиным. - Н. Д.) [Там же, с. 288].

Завершением размышлений о счастье всех и каждого является, с нашей точки зрения, мысль о двух законах жизни:

Тот и другой законы, и для себя и для всех - эгоизм и общее дело, поодиночке чудовищны, но в борьбе того и другого рождается личность [Там же, с. 222]. 


\section{Счастье и правда}

Ключевой для понимания «Корабельной чащи», с нашей точки зрения, является дневниковая запись Пришвина о том, что «слово правды делается всеми человеческими и нечеловеческими правдами и неправдами, а не тобой одним» [Пришвин, 2017a, с. 411]. Писатель называет «Корабельную чащу» повестью-сказкой, ставя ее в один ряд с «Женьшенем», герой которого сознательно выходит из войны и обращается к творчеству «новой, лучшей жизни людей на земле» [Пришвин, 1982-1986, т. 4, с. 78]. Не случайно действие в повести происходит главным образом весной 1945 г.

«Лесная повесть» Пришвина - в соответствии с логикой ее сюжета - сказка о «заповедной корабельной чаще» как народной «святыне» и ее спасении, в котором участвуют «хорошие простые люди» и небеса. В романе «Журавлиная родина» (1929) Пришвин уже создавал сюжет о спасении одного-единственного живого существа - реликтовой водоросли кладофоры. Герой и автор «Журавлиной родины» отказываются от идеи создания «Золотой луговины» (общества социального благоденствия), если это будет сделано ценой гибели озера и живущего в нем уникального растения. Роман стал историей о защите каждого в условиях победы всех. Корабельная чаща, в которой «дерево стоит за всех и все деревья стоят за каждое» [Пришвин, 1984, c. 221, 411, 416], - сказочный символический образ правды истинной, фиксирующий попытку Пришвина найти такую идеальную форму жизни, в которой признаются, как он пишет, равные права закона всех и закона каждого и которая является народной святыней.

Правда истинная в лесной повести Пришвина предстает не в виде некой известной величины, а понимается как путь, общий для всех и особенный для каждого. Авторская позиция в повести возникает из взаимодействия трех точек зрения: советской (В. Веселкин), народной (Мануйло, полесники, охотники, «мы» как форма субъекта речи), иносказательной религиозной, представленной фразами, подобными следующей: «Свет великий, могучий и страшный» [Там же, с. 224].

Благодаря Мануйле, сказочнику и охотнику, в «Корабельной чаще» появляется тема охоты, полемически обращенная к рассказу «Охота за счастьем». Самая значительная из охотничьих историй в повести, по нашему мнению, это история о поющих глухарях, дом жизни которых - Красные Гривы - уничтожили, оставив на месте деревьев пни, где они сидели и пели. В их пении о неуничтожимости и непобедимости жизни охотники расслышали вечный человеческий закон: помирать собирайся - рожь сей. Эта история диалогически обращена к истории птиц, парящих в воздухе над разрушенным храмом Христа Спасителя [Пришвин, 2006, с. 588].

«Дневники» фиксируют сомнения и тревогу Пришвина о судьбе «Корабельной чащи», вышедшей в свет в «Новом мире» Твардовского 
уже после смерти автора. Его восприятие «Корабельной чащи» внутренне противоречиво. Он, например, пишет о ней: “Слово правды” вышла повесть чистая, вроде Храма». Он вместе с тем анализирует ситуацию с редактором В. И. Пелевиным, который «попробовал читать “Чащу" и бросил», видя в ней приспособление, «сергианство» Пришвина, объясняя которое, писатель утверждает: «В нравственном плане оказывается невозможным стать на ту сторону, и оттого тянет стать на свой камень» [Пришвин, 2017a, с. 388, 443].

«Дневники» с их живой сложностью и «Корабельная чаща» с ее сказочной простотой дополняют и толкуют друг друга.

В пришвинском тексте счастья отчетливо выделяются два направления: воссоздание опыта переживания жизни как счастья/несчастья и осмысление феномена счастья. Первое фиксируется в основном в «Дневниках», второе - в художественных произведениях и «Дневниках».

Текст счастья в творчестве Пришвина структурируется системой лейтмотивов: жизнь как счастье; счастье и несчастье; счастье всех и каждого; лестница счастья; путь к счастью; счастье, которое добывается и которое дается как дар и чудо; охота за счастьем; счастье и правда и др.

Пришвинский текст счастья свидетельствует о единстве миропонимания писателя досоветского и советского периодов. Изменение смыслов мотивов счастья в его творчестве определяется не внешними социально-историческими обстоятельствами времени, «проектом советской эпохи», а логикой его пути «строительства борьбы за жизнь вне идейного человека», и прежде всего духовным переворотом 1930-1940-х гг., в результате которого меняются его представления о счастье всех и каждого.

\section{Список литературы}

Варламов А. Н. Пришвин. М. : Молодая гвардия, 2003. 848 с.

Гаспаров Б. М. Литературные лейтмотивы : Очерки по русской литературе ХХ века. М. : Наука, 1993. 304 с.

Добренко $E$. А. Рецензия на кн. : Топография счастья: этнографические карты модерна / сост. Н. В. Ссорин-Чайков. М. : Новое лит. обозрение, 2013. 408 с. // Антропологический форум. 2015. № 25. С. 165-172.

Ершов Г. А. Михаил Пришвин: жизнь и творчество. М. : Худож. лит., 1973. 192 с.

Курбатов В. Я. Михаил Пришвин: жизнеописание идеи. М. : Сов. писатель, 1986. $224 \mathrm{c}$

Лоргус А. Книга о счастье. М. : Никея, 2017. 144 с.

Подоксенов А. М. Художественный мир Михаила Пришвина в контексте мировоззренческого дискурса русской культуры ХХ века. Елец : Елец. гос. ун-т им. И. А. Бунина ; Кострома : Костром. гос. ун-т им. Н. А. Некрасова, 2012. 334 с.

Пришвин М. М. Собр. соч. : в 8 т. / под ред. В. В. Кожинова и др. М. : Худож. лит., 1982-1986. 
Пришвин М. М., Пришвина В. Д. Мы с тобой : Дневник любви. М. : Худож. лит., 1996. $351 \mathrm{c}$.

Пришвин М. М. Дневники. 1920-1925. М. : Моск. рабочий, 1995. 334 с.

Пришвин М. М. Дневники. 1923-1925. М. : Рус. книга, 1999. 416 с.

Пришвин М. М. Дневники. 1926-1927. М. : Рус. книга, 2003. 592 с.

Пришвин М. М. Дневники. 1930-1931. СПб. : Росток, 2006. 704 с.

Пришвин М. М. Дневники. 1936-1937. СПб. : Росток, 2010. 992 с.

Пришвин М. М. Дневники. 1940-1941. М. : РОССПЭН, 2012. 880 с.

Прищвин М. М. Дневники. 1952-1954. СПб. : Росток, 2017а. 832 с.

Пришвин М. М. Ранний дневник. 1905-1913. СПб. : Росток, 2007. 800 с.

Пришивин М. М. Цвет и крест / сост. В. А. Фатеев. СПб. : Росток, 2017б. 608 с.

Рязанова Л. А. Благодарности // Пришвин М. М. Дневники. 1952-1954. СПб. : Росток, 2017. С. 3-4.

Топография счастья : Этнографические карты модерна : сб. ст. / сост. Н. В. Ссорин-Чайков. М. : Новое лит. обозрение, 2013. 408 с.

Хайлов А. И. Пришвин: творческий путь. М. ; Л. : Изд-во Акад. наук СССР, 1960. $163 \mathrm{c}$.

Хмельницкая Т. Ю. Творчество Михаила Пришвина. Л. : Сов. писатель, 1959. $284 \mathrm{c}$.

Худенко $E$. А. Киргизская степь в путевых записках и очерках М. М. Пришвина: имагология и поэтика // Проблемы исторической поэтики. Т. 15. 2017. № 2. С. 107118. DOI 10.15393/j9.art.2017.4322.

Чинакова Н. В. Экономика счастья: современные исследования и дискуссии // Мир экономики и управления. Т. 16. 2016. № 1. С. 101-115.

Электронная библиотека M. M. Пришвина : [сайт]. URL: http://elsu.ru/prishvin. html (дата обращения: 20.03.2019).

\section{References}

Chinakova, N. V. (2016). Ekonomika schast'ya: sovremennye issledovaniya i diskussii [The Economics of Happiness: Modern Research and Discussions]. In Mir ekonomiki i upravleniya. Vol. 16. No. 1, pp. 101-115.

Dobrenko, E. A. (2015). Retsenziya na knigu: Topografiya schast'ya: Etnograficheskie karty moderna [Book Review: Ssorin-Chaikov, N. V. (2013). The Topography of Happiness: Ethnographic Maps of Modernity. Moscow, Novoe literaturnoe obozrenie. 408 p.]. In Antropologicheskii forum. No. 25, pp. 165-172.

Elektronnaya biblioteka M. M. Prishvina [Electronic Library of M. M. Prishvin] [website]. URL: http://elsu.ru/prishvin.html (mode of access: 20.03.2019).

Ershov, G. A. (1973). Mikhail Prishvin: zhizn'i tvorchestvo [Mikhail Prishvin: Life and Literary Works]. Moscow, Khudozhestvennaya literatura. 192 p.

Gasparov, B. M. (1993). Literaturnye leitmotivy. Ocherki po russkoi literature XX veka [Literary Leitmotifs. Essays on the Russian Literature of the $20^{\text {th }}$ Century]. Moscow, Nauka. 304 p.

Khailov, A. I. (1960). Prishvin: tvorcheskii put' [Prishvin: The Creative Journey]. Moscow, Leningrad, Izdatel'stvo Akademii nauk SSSR. 163 p.

Khmel'nitskaya, T. Yu. (1959). Tvorchestvo Mikhaila Prishvina [Mikhail Prishvin's Oeuvre]. Leningrad, Sovetskii pisatel'. 284 p.

Khudenko, E. A. (2017). Kirgizskaya step' v putevykh zapiskakh i ocherkakh M. M. Prishvina: imagologiya i poetika [The Kyrgyz Steppe in Travel Notes and Essays: Imagology and Poetics]. In Problemy istoricheskoi poetiki. Vol. 15. No. 2, pp. 107-118. DOI 10.15393/j9.art.2017.4322.

Kurbatov, V. Ya. (1986). Mikhail Prishvin: zhizneopisanie idei [Mikhail Prishvin: A Biography of Ideas]. Moscow, Sovetskii pisatel'. 224 p.

Lorgus, A. (2017). Kniga o schast'e [A Book about Happiness]. Moscow, Nikeya. 144 p. 
Podoksenov, A. M. (2012). Khudozhestvennyi mir Mikhaila Prishvina v kontekste mirovozzrencheskogo diskursa russkoi kul'tury XX veka [The Artistic World of Mikhail Prishvin in the Context of the Worldview Discourse of $20^{\text {th }}$-Century Russian Literature]. Elets, Eletskii gosudarstvennyi universitet imeni I. A. Bunina, Kostroma, Kostromskoi gosudarstvennyi universitet imeni N. A. Nekrasova. $334 \mathrm{p}$.

Prishvin, M. M. (1982-1986). Sobranie sochinenii v 8 t. [Collected Works. 8 Vols.] / ed. by V. V. Kozhinov et al. Moscow, Khudozhestvennaya literatura.

Prishvin, M. M. (1995). Dnevniki. 1920-1925 [Diaries. 1920-1925]. Moscow, Moskovskii rabochii. $334 \mathrm{p}$.

Prishvin, M. M. (1999). Dnevniki. 1923-1925 [Diaries. 1923-1925]. Moscow, Russkaya kniga. $416 \mathrm{p}$.

Prishvin, M. M. (2003). Dnevniki. 1926-1927 [Diaries. 1926-1927]. Moscow, Russkaya kniga. 592 p.

Prishvin, M. M. (2006). Dnevniki. 1930-1931 [Diaries. 1930-1931]. St Petersburg, Rostok. 704 p.

Prishvin, M. M. (2007). Rannii dnevnik. 1905-1913 [The Early Diary. 1905-1913]. St Petersburg, Rostok. 800 p.

Prishvin, M. M. (2010). Dnevniki. 1936-1937 [Diaries. 1936-1937]. St Petersburg, Rostok. 992 p.

Prishvin, M. M. (2012). Dnevniki 1940-1941 [Diaries. 1940-1941]. Moscow, ROSSPEN. 880 p.

Prishvin, M. M. (2017a). Dnevniki. 1952-1954 [Diaries. 1952-1954]. St Petersburg, Rostok. 832 p.

Prishvin, M. M. (2017b). Tsvet i krest [The Colour and the Cross] / ed. by V. A. Fateev. St Petersburg, Rostok. 608 p.

Prishvin, M. M., Prishvina, V. D. (1996). My s toboi. Dnevnik lyubvi [You and I. A Diary of Love]. Moscow, Khudozhestvennaya literatura. 351 p.

Ryazanova, L. A. (2017). Blagodarnosti [Acknowledgements]. In Prishvin, M. M. Dnevniki. 1952-1954. St Petersburg, Rostok, pp. 3-4.

Ssorin-Chaikov, N. V. (Ed.). (2013). Topografiya schast'ya: Etnograficheskie karty moderna [The Topography of Happiness: Ethnographic Maps of Modernity]. Moscow, Novoe literaturnoe obozrenie. $408 \mathrm{p}$.

Varlamov, A. N. (2003). Prishvin [Prishvin]. Moscow, Molodaya gvardiya. 848 p.

The article was submitted on 01.04.2019 